POLISH POLITICAL SCIENCE

VOL XXXIX 2010

PL ISSN 0208-7375

\title{
A RIGID VIEW OF SOVEREIGNTY IN INTERNATIONAL DIPLOMACY
}

\author{
by Wojciech Stankiewicz
}

Sovereignty is a broad based concept which grants enormous powers to heads of states within their boundaries. That power may sometimes pave the way for the abuse of sovereignty. There are many cases throughout history where the States tended to use their sovereign powers beyond their limits and tried to extend their sovereignty in an abusive manner, either within or outside their territory.

In this paper, the research hypothesis is the statement that a rigid approach to sovereignty might cause the reasons for rising of conflicts between States in diplomatic relations. The main aim of this paper is to elaborate the concept of sovereignty in order to develop an understanding of the functions of a sovereign and examine the cases resulted from the rigid use of sovereignty. ${ }^{1}$ The paper also aims to explore in what ways international diplomacy can contribute to prevent abuses of sovereignty by States.

1 State sovereignty in the 21st century: concept, relevance and limits: proceedings of an international seminar held at New Delhi, July 23-24 2001 organised by Institute for Defence Studies and Analyses and Indian Council of World Affaires, New Delhi: Institute for Defence Studies and Analyses 2001. 
This paper initially will focus on the definition of the meaning of sovereignty. Then, functions of the sovereign will be elaborated. Also, the rigid use of sovereignty and why it was necessary to use it as such in the past will be discussed within the historical context.

Moreover, three cases where States were taken to international courts because their rigid view of sovereignty, will be examined. As can be understood from historical experience and from the Principles of International Law, states should use their sovereignty in a flexible manner when they engage in diplomatic relations. International Diplomacy should be based on improvement of cooperation amongst States through development of economic relations.

Therefore, the paper fill finally focus on the functions of international diplomacy to elaborate in which ways international diplomacy can help adopt a flexible attitude to sovereignty of States.

To prove the present hypothesis, it is essential to attempt to answer the following questions:

1. How might the concept of sovereignty be defined?

2. How have the approaches to different aspects of sovereignty historically developed?

3. What functions does sovereignty perform?

4. How should the functions of a sovereign be understood?

5. How does the selected cases within the historical context show the impact of the rigid use of sovereignty?

6. Which of mentioned cases were taken by States to international courts because their rigid view of sovereignty?

7. In what ways international diplomacy can contribute to prevent abuses of sovereignty by States?

8. In what ways international diplomacy can help to adopt a flexible attitude to sovereignty of States?

\section{DEFINITION OF SOVEREIGNTY}

The term or concept sovereignty in its literally meaning means omnipotence that is all powerful. In essence it means state can do and undo 
anything as it wishes within its territorial jurisdiction. ${ }^{2}$ That state has unchallenging powers over its domestic affairs, territorial waters, airspace, foreign policies, trade policy as well as its fiscal matters. Thus, from this above definition one can say that sovereignty is a fundamental principle of international public law.

With the accordance to Alain de Benoist (2000) the concept of sovereignty is one of the most complex in political science, with many definitions, some totally contradictory. ${ }^{3}$ Usually, sovereignty is defined in one of two ways. The first definition applies to supreme public power, which has the right and, in theory, the capacity to impose its authority in the last instance. The second definition refers to the holder of legitimate power, who is recognized to have authority. When national sovereignty is discussed, the first definition applies, and it refers in particular to independence, such as the freedom of a collective entity to act. When popular sovereignty is discussed, the second definition applies, and sovereignty is associated with power and legitimacy. ${ }^{4}$

According to Chatterjee ${ }^{5}$ (2007) "sovereignty means omnipotence". The term omnipotence means all powerful. The sovereign, who is the head of the State, as Chatterjee sets out, "can do or undo anything within its territorial jurisdiction" and sovereign is the "law-maker" who has the opportunity to opt to be accountable towards the citizens, depending on the system of the State (whether democratic or not). Sovereign, according to Chatterjee, also has the authority to dominate internal matters including "fiscal matters". Moreover, sovereign has the authority extended to include its territorial waters and airspaces. He continues by stating that, sovereigns

2 M. Akehurst, Jurisdiction in International Law, "British Year Book of International Law" 1974, No. 46.

3 C. Merriam, History of the Theory of Sovereignty since Rousseau, Batoche Books Kitchener 2001, p. 12-17.

4 A. de Benoist, What is Sovereignty?, 30 March 2000, http://www.alaindebenoist. com/pdf/what_is_sovereignty.pdf, 12 May 2007.

5 Professor Chatterjee is a Barrister in England and Wales. He has an LL.M. from the University and an LL.M. Ph.D. from the University of London. His areas of specialisation are public international law and international and commercial law. He has published a considerable number of books and articles on various issues of public international law and international commercial law. 
have the sole appreciation as to whom they will engage into diplomatic relations and can also terminate the relations as they wish. Chatterjee underlines that, sovereign has the power to decide whether to foster foreign investment in their country or not and sovereign also has the authority to dominate foreign and trade policy of the State. ${ }^{6}$

From the economic point of view, also interesting to mention, $\mathrm{Kal}$ Raustiala ${ }^{7}$ has analysed various approaches to the concept of sovereignty and she realized that Many observers argue that sovereignty is threatened by the ongoing expansion of international economic institutions. She also argues that institutions such as the World Trade Organization in fact strengthen sovereignty. Her theory collectively highlights an underexplored proposition: that changes in the international system or in domestic politics have already compromised sovereignty and thus international institutions, while rendering the erosion of sovereignty more legible, actually serve as a means to reassert or reclaim sovereignty. These ideas are important for two reasons. First, they challenge prevailing wisdom and thus offer an alternative guide for policy. Second, they suggest that our conceptions of sovereignty are unduly narrow and may be increasingly anachronistic. In particular, scholars must consider more deeply the purpose and role of sovereignty in the contemporary world. ${ }^{8}$

Jackson defines the sovereign state as the most superior authority compared with all other institutions within the given territory, in the sense that sovereign's decisions cannot be appealed. According to Jackson, "a sovereign is not subordinate to anybody", but anyone who is subject to its authority is accountable to the sovereign. ${ }^{9}$ Chatterjee sets out that, "a sovereign is not amenable to any other sovereign; the principle being that all sovereigns are equal."10

\footnotetext{
6 C. Chatterjee, International Law and Diplomacy, Routledge, London 2007, p. 36.

7 Acting Professor, UCLA Law School and Institute of the Environment, University of Oxford.

8 K. Raustiala, Rethinking the sovereignty debate in International economic Law, "Journal of International Economic Law" 2003, Vol. 6, No 4, pp. 841-878.

9 R. Jackson, Sovereignty: Evolution of an Idea, Cambridge U.K.: Polity Press 2007, p. 10.

10 C. Chatterjee, op.cit., p. 37.
} 
Krasner (1999) argues that there are four types of sovereignty, namely, "international legal sovereignty, Westphalian sovereignty, domestic sovereignty and interdependence sovereignty". He describes the international legal sovereignty as the relations between the mutually recognised "territorial entities which have formal juridical independence". Westphalian sovereignty ${ }^{11}$, according to Krasner, is based on the political entity which outlaws foreign components from the ruling mechanism over a certain territory. Domestic sovereignty, on the other hand, is the governance system in the state, based on the effective rule of state institutions within the given territory. Interdependence sovereignty, to Krasner, is the capability of rulers to allow the mutual "flow of information, ideas, goods, people, pollutants, or capital" beyond their territories. ${ }^{12}$

\section{HISTORY OF SOVEREIGNTY}

On the one hand, sovereignty can be best understood more precisely only through its history. It's vital to note that there was an evolution towards an European continent which took the form of a movement which later metamorphosized into a globe of sovereign states. In this aspect it's vital to note that it was the Peace of Westphalia in 1648 that Europe consolidated its long transition from the middle ages of a world of sovereign states. According to J.R. Strayer Britain and France looked like sovereign states at about 1300, because their kings possessed supremacy within their bounded territories. ${ }^{13}$

However, in 1555 a system of sovereign states gained vital grounds in the Peace of Augsburg which allowed German princes to enforce their own faiths within their territory, but it was unstable, consequently it resulted to 30 years of war which ended in 1648, thus Westphalia was regarded as the origin of the sovereign state system in two ways.

11 Re-envisioning sovereignty: the end of Westphalia? Ed. by T. Jacobsen, C. Sampford, R. Thakur, Burlington, VT: Ashgate, Aldershot 2008.

12 S.D. Krasner, Sovereignty: Organised Hypocrisy, Princeton University, New Jersey 1999, p. 4-5

13 Sovereignty, www.standford.edu/entries/sovereignty, 17 May 2007. 
First and foremost, states emerged as the sole form of substantial constitutional authority in Europe, because their authority was no longer seriously challenged by the Holy Roman Empire and also the temporal powers of the Church were also curtailed to the point that they no longer challenged the state sovereignty, in response to that Pope Innocent $\mathrm{X}$ condemned the treaties of the people as null, invalid, unjust, damnable, reprobate, inane, empty of meaning and effect for all.

Secondly, Westphalia ended the intervention in matters of religion up to the most commonly practiced abridgement of sovereign prerogatives it was consolidated on the Peace of Augsburg but not in the exact form of 1555,14 it effectively established the authority of princes and kings over religion so that no European state would fight to affect the religious governance of another state. As a result of this it culminated in the decline of European colonial empires in the mid-20th century which became the only form of polity over the entire globe.

Today, norms of sovereignty are embedded in the charter of the United Nations like article 2[4] which prohibit attacks on political independence and territorial integrity of states. ${ }^{15}$ It's vital to note that Jean Bodin ${ }^{16}$, a French philosopher was the first to treat the concept of sovereignty extensively in his work De La Republique in 1576 during a civil war in France between the Calvinist Huguenets and the Catholic Monarchy. He saw the problem of order as central and believed that it could be solved if man is regarded as supreme in governance, because he believed that sovereign is needed for controlling people and in religion which he argued that GOD is supreme over man.

However some old fashioned thinkers argued that sovereign is individualistic and indivisible and is not accountable to anyone. This school of thought is not favourable for developing international relations.

On the other hand, the historical process where the modern sovereign system replaced the divine rule is worth examining in order to understand

14 Ibidem

15 Ibidem.

16 S. Beaulac, Powers of language in the making of international law: the word sovereignty in Bodin and Vattel and the myth of Westphalia, Martinus Nijhoff Publishers, Leiden; Boston: 2004. 
the reason why the rulers had been maintaining a rigid view on sovereignty throughout history.

Jackson (2007) stated that, in the Middle Ages, "Latin Christendom and "Greek Byzantine Empire" existed as two Christian empires, the former in Rome and the latter being in the Constantinopole (Istanbul). He continued that, in the long run, Latin Christendom was replaced by the modern sovereign, while on the other hand, the Ottoman rule over the Byzantine Empire in the 15th century postponed the formation of sovereign states in the Ottoman ruled parts of the world, where nationstates came existent only in the end of 19 th and the beginning of 20 th centuries. ${ }^{17}$

According to Knowles (1967), in that time "the King was regarded as the sole authority, the representative of God, to whom subjects owed a quasi-religious obedience."18

The transformation from "medieval" to "modern" according to Jackson, realised with the establishment of the "sovereign state". As Jackson set out, that initially occured with the formation of independent city-states which transformed into a state system at the time of Renaissance during the 14th and the 15th centuries. He explained that other European powers adopted the Italian model, named as the "Protestant Reformation", with the span of Renaissance towards northern Europe, which was initially applied by Germany. ${ }^{19}$

According to Jackson, the sovereign state had became over religion in the subject matter of war with the Peace of Ausburg (1555) where "German Lutherans" and "Catholics" agreed on the doctrine with that military intervention should not be justified with religious causes. He pointed out that Treaty of Westphalia of 1648, which ended the Thirty Years War (1618-48) was a turning point in the history of Europe, as it drastically erased the traces of the papal rule over foreign relations and underlined that the European States were "independent entities". ${ }^{20}$

17 R. Jackson, op.cit., p. 25.

18 D. Knowles, The Religious Orders in England, Cambridge University Press, Cambridge 1967, p. 12.

19 R. Jackson, op.cit., p. 37.

20 Ibidem, p. 50. 
The transformation from "dynastic sovereignty" to the modern state system was finalised with the Peace of Utrecht (1713). Jackson stated that, with the Peace of Utrecht, which ceased the War of Spanish Succession, it was agreed that national interests were above the dynastic rights in the international affairs. That transformation of Europe, according to Jackson was from "a transitional political-theological world, a Catholic Christian theocracy, to a modern secular world based on a system or society of sovereign states". ${ }^{21}$ By the eighteenth century, secular Eurpean state system was emerged in which state sovereignty was widely embraced as the base of internal and international politics, where there were no more religious authority over political affairs, as Jackson pointed out. ${ }^{22}$

According to Chatterjee, when the concept of sovereignty was carried forward in the 16th century by Machiavelli and Bodin and later in the 17th century by Hobbes, it was essentially practised in an abusive manner in order to challange the structure of the medieval Christendom. Chatterjee refered to Bodin's suggestion at that time that, in order to cope with the disordered situation in France in the 17th century, the power of the sovereign was used in such a dictatorial way that the sovereign's dictates would be regarded by people as the law. He provided that, Bodin's dictarorial ideas lost ground, especially in the West, with the emergence of Parliaments in the 18th century, which were leaned on a democratic basis. However, as Chatterjee suggests, some sovereigns still perceive sovereignty as Bodin - "indivisible, omnipotent and unamenable to anyone."23

\section{FUNCTIONS OF SOVEREIGN}

On the one hand, Chatterjee sets out the functions of the sovereign as; protecting national interests; law-making; developing foreign relations; domestic matters (health, education, finance, defence, law and justice, trade etc.) and developing norms of international law. ${ }^{24}$

\footnotetext{
21 Ibidem, p. 52.

22 Ibidem, pp. 53-54.

23 C. Chatterjee, op.cit., p. 48.

24 Ibidem, p. 56
} 
From the above-mentioned functions it is clear that, sovereign, besides ruling the country, should engage into diplomatic activities that would contribute to the international law making process. ${ }^{25}$ As Chatterjee mentioned, with the aim of protecting their national interests, land-locked states, for instance, engaged into negotiations when the International Law of the Sea Convention was drafted. Therefore, international diplomacy can be used as a mean to protect national interests.

On the other hand, simply it can be point out that first function of sovereignty is law making. Since, sovereignty is all powerful [omnipotence], then it has total control over its territorial jurisdiction i.e territorial waters, airspace, domestic matters, foreign and trade policy, thus it is the law maker, it is vital to note that a democratic sovereign will justify the necessity of a particular legislation, while a non-democratic sovereign need not to. ${ }^{26}$

Second function can be the impact on International or Foreign Relations. In reference to this since sovereignty has total control over its foreign policy, likewise trade, hence it uses its initiative to decide with whom it wants to establish diplomatic relations with or not through the means of bilateral treaties or multilateral. Privileges can be based on historical grounds which is vividly seen in the Viennna Convention on Diplomatic Relations, 1961, Article 2[a] and [b] and also in Article 72[a] and [b] of the Convention on Consular Relations. ${ }^{27}$

Another function of Sovereignty is in the sphere of international cooperation, it means sovereignty goes beyond its national interest to develop international laws for the international community as a whole ${ }^{28}$, on issues

$25 \mathrm{~J}$. Bartelson, Playing with sovereignty: examples from the theory and practice in international law, [in:] Sovereignty games: instrumentalizing state sovereignty in Europe and beyond, ed. by R. Adler-Nissen and T. Gammeltoft-Hanses, Palgrave Macmillan, New York 2008.

26 S.D. Krasner, op.cit., p. 45.

27 The Viennna Convention on Diplomatic Relations, 1961,Article 2[a] and [b] and the Vienna Convention on Consular Relations, Article 72[a] and [b].

28 Towards an 'international legal community'?: the sovereignty of states and the sovereignty of international law, ed. By C. Warbrick and S. Tierney, British Institute of International and Comparative Law, London 2006. 
like environmental protection, money laundering and terrorism which an individual state doesn't have full control of. ${ }^{29}$

Lastly, sovereignty has the primary function to protect its national interest and the genuineness of it may not be questioned.

\section{THE RIGID VIEW OF SOVEREIGNTY AND DECIDED CASES}

Chatterjee points out that, as the sovereign has the complete jurisdiction within its own territory (absoluteness) and as "sovereignty is indivisible", neither granted to someone else nor divided (indivisibility), this may allow sovereigns to use their powers rigidly in the sense that, the sovereign may not wish to cooperate with other States and might perceive international organisations as jeopardizing their power. ${ }^{30}$

The sovereigns may abuse their powers internally and also with their relations with other states. According to Chatterjee, if the head of the state is despotic and prevents the citizens from enjoying their fundamental rights, this is considered as an internal abuse of power, which might also negatively affects the diplomatic relations of the State. ${ }^{31}$

In cases of extending sovereignty across the borders of a country, Chatterjee points out that, the issue of extra-territoriality comes into light. As sovereignty is associated with territory (if sovereign is only allowed to exert power within its borders), within the given territories of the state "sovereigns jurisdiction is unchallengeable". However, the sovereign may be allowed to use its power beyond its territory only if there is a bilateral agreement with the other sovereign, or if international law permits as such. In case of extra-territoriality, the State implicitly extends its sovereignty (power, judicial orders and laws) to the other State, which gives the other State the right to take the matter as an international claim. The extraterritorial act, therefore is not allowed in international law, unless it is suppoted by a treaty between the two States. ${ }^{32}$




Shaw (2003) argues that "states are accountable for the breaches of international law, therefore, the injured state can maintain a claim against the violating state, whether by way of diplomatic action or by way of recourse to international mechanisms where such are in place with regrad to the subject matter at issue." 33

Another, rigid view of sovereignty can be exemplified in Article 2[7] of the United Nations Charter, which states that:

"Nothing contained in the present Charter shall authorize the United Nations to intervene in matters which are essentially within the domestic jurisdiction of any state or shall (...) but this principle shall not prejudice the application of enforcement measures under Chapter VII." ${ }^{34}$

This Article can be viewed as rigid in the context of sovereignty because of the word 'intervention' which has provoked controversy, which has led to the development of two school of thoughts, in which one led by Goodrich and Hambro pointed out that the term shouldn't be given a narrow technical concept, while the other school led by Sir Hirsch Lauterpacht emphasized that it should be understood from its technical meaning, that is dictatorial interference by the United Nations should be avoided. ${ }^{35}$ This view is still controversial in this word about true is the use of sovereignty via a truly international organization.

Three cases, namely the River Oder Commission Case, Oscar Chinn Case, and Wimbledon Case will be discussed, as examples of how the rigid view of sovereignty by States resulted with international claims.

\section{THE TERRITORIAL JURISDICTION OF THE INTERNATIONAL COMMISSION ON THE RIVER ODER}

The Case Relating to the Territorial Jurisdiction of the International Commission on the River Oder was raised by the United Kingdom, Czechoslovakia, Denmark, France, Germany, Sweden versus Poland in

33 M.N. Shaw, International Law, Cambridge University Press, Cambridge 2003, p. 760 .

34 Article 2[7], Chapter VII, The United Nations Charter.

35 H. Laukerpacht, Hague Recveil, 1947 no 70, p. 31. 
1929 to the Permanent Court of International Justice regarding the river Oder. The question was about the "disagreement on the territorial limits of the jurisdiction of the International Commission of the Oder, as to, whether its jusrisdiction extend to the sections of the tributaries of the Oder which are situated in the Polish territory". ${ }^{36}$

As Shaw explained, the Permanent Court of International Justice decided that the Commission's jurisdiction did extend and noted that that the "community of interest" of riparian states to use the navigable river creates an essential legal right that the whole course of river should be used by the concerned states without being subject to any discrimination. ${ }^{37}$

Chatterjee stated that, in that particular case, it was made clear that, empowering the Commission to provide imperative efficiency in maintenance of the river, will not mean that the riparian States will relinguish their sovereignty to that commission..$^{38}$

As understood, Poland was pursuing a rigid view of sovereignty by not willing to surrender its sovereignty to the Commission. However, as there was a common interest of the concerned States, Poland required to use its sovereignty in a cooperative manner.

On the other hand, it can be the flexible view of sovereignty whereby sovereign states are needed to adopt a flexible attitude towards sovereignty, which is the bedrock of international cooperation. In this case the common interest of states is likely to be well protected by the international organizations. This can be exemplified in the River Oder Commission case, whereby an external body was set up with the aim of maintaining the operational efficacy and up keep of the river by the riparian states. Hence, this type of sovereignty can be seen as co-operative sovereignty. ${ }^{39}$

In addition another example can be the European Union in which the European states are sovereign in governing defence, but not in governing their currencies, trade policies and many social welfare policies which is

\footnotetext{
36 World Court - international third-party dispute settlement institutions http:// www.worldcourts.com/pcij/eng/decisions/1929.09.10_river_oder/, 15 May 2007.

37 M.N. Shaw, op.cit., p. 760.

38 C. Chatterjee, op.cit., p. 47.

39 H. Lauterpacht, op.cit., p. 31.
} 
being administered in co-operation with the E.U authorities as being drafted in the EU law. ${ }^{40}$

Furthermore, a degree of flexibility can be seen in the application of Article 2[7] of the UN Charter, whereby most of the former colonies joined the United Nations as independent sovereign states. ${ }^{41}$

\section{THE OSCAR CHINN CASE}

An example is the Oscar Chinn Case, ${ }^{42}$ where the Permanent Court's attitude towards sovereignty under an international treaty proved to be rigid. Mr. Chinn, a British subject established a river transport and shipbuilding and repairing business in Leopoldville, which was operated under auspices of the Belgian government till 1925, which was later transferred to a company known as Sonatra, before it became the Union Nationale des transports fluviaux, which the state owned more than 70,000 shares out of 120,000 .

Thus, during the commercial depression in the 1930's, the Belgian Minister for the Colonies reduced the net price of some goods which included the expenses of transportation, handling and rates for the carriage which Chinn found it frustrating to run his business, thus he had to fold up his business in 13 May 1931, because of the losses he incurred, though the Minister confirmed that governmental assistance must be confined to transport undertakings over those rates the Government had a right of supervision. Thus, Mr.Chinn took an action against the Colony in the Court of First Instance and Court of Appeal, but both courts found against him.

Hence, he appealed to his Government for protection and took up his claim, it is vital to note that in the Permanent Court, the dispute was based on the Convention of Saint-German-en-Laye of 10 September 1919, Article 1 which provides that:

\footnotetext{
40 R. Jackson, op.cit., p. 87.

41 Article 2[7], The United Nations Charter.

42 Permanent Court of International Justice [1934] series A/B, p 74.
} 
"The signatory Powers undertake to maintain between their respective nationals and those of States, Members of the League of Nations, which may adhere to the present Convention a complete commercial equality in the territories under the authority within the area defined by Article 1 of the General Act of Berlin of February 26th, 1885 set out in the Annex hereto, but subject to the reservations specific in the final paragraph of that Article." 43

To this end the Government of Great Britain indentified three legal issues and submitted it to the Permanent Court of International Justice amongst the legal was that 'whether by enjoining a reduction of tarrifs on Untara in return for a promise of temporary pecuniary compensation, the Belgian Government did not make it impossible for the other fluvial transporters, including Mr.Chinn, to retain their customers and enabled Unatra to exercise a de facto monopoly which was incompatible with the Belgian Government's obligation to maintain commercial freedom and equality; and also with the obligation arising out of Article 5 of the Convention of Saint - Germain, which applies those principles to fluvial navigation. ${ }^{4}$

In response to that the Belgian government maintained that:

\begin{abstract}
The measures which it took were necessary to safeguard the interest of its community due to the position of the colonial products in the world market, that it wasn't its deliberate intention to create a monopoly of any kind for Unatara so as to eliminate competitors out of business, that the which it took were lawful from the viewpoint of international law be it conventional or customary. It also declared that a distinction between the sphere of navigation and management of national shipping must be drawn. ${ }^{45}$
\end{abstract}

The court maintained that:

\footnotetext{
43 Ibidem, p. 75.

44 Ibidem, p. 82.

45 Ibidem, p. 83.
} 
(...) freedom of navigation by the Convention comprises freedom of movement of vessels as far business side of maritime or fluvial transport is concerned, but doesn't imply that other respects of freedom of navigation entails and presupposes freedom of commerce. ${ }^{46}$

In essence it means that the Court recognized the freedom of navigation and as two separate concepts within the context of the case in principle, also coupled with this that the Court asserted that the Convention of Saint-German was based on the idea of commercial freedom, but the idea didn't have the same import in the Convention as in the Act of Berlin.

Hence, the Court rejected the British government's argument by six votes to five that a monopoly of any nature was established by the Belgian Government, it also maintained that if a monopoly was established others were bound to respect it and that it wasn't in conflict with the international obligations of the Belgian Government towards the Government of United Kingdom.

According to Jugde van Eysinga who had a different opinion from other judges stated that: "If the Belgian Government argument is about the freedom of fluvial navigation (...) and leaving the commercial aspect of it, it therefore means that it adopted a diametrically opposite viewpoint, by interpreting fluvial navigation by the provisions relating to the liberty of commerce. Thus it means the truth lies mid-way between the two stand points. It therefore means that the Belgian Government maintained a rigid notion towards sovereignty to protect its national commercial entity in lieu of its international obligations towards the Government of the United Kingdom." 47

As Chatterjee pointed out, "the Permanent Court's attitude towards sovereignty under an international treaty proved to be rather rigid". States shouldn't treat in a discriminatory manner to the foreign companies operating within their territory. Such a discrimination is considered as the abuse of sovereignty.

\footnotetext{
46 Ibidem.

47 World Court - international third-party dispute settlement institutions http:// www.worldcourts.com/pcij/eng/decisions/1934.12.12_oscar_chinn/, 15 May 2007.
} 


\section{THE WIMBLEDON CASE}

In Wimbledon Case, Wimbledon was a British vessel chartered by a French company which seek to pass the Kiel Canal on 21 March 1921 and refused the right of passage by the German authorities. Germany claimed that "Wimbeldon was carrying military equipment to Poland which was then at war with Russia". Britain, France, Italy and Japan, with intervention of Poland, sought a judgement in 1923 before the Permanent Court of International Justice, that "German authorities had broken their treaty obligations and asked for damages with interest". The court made it clear that the Kiel Canal should be open to passage by the countries at peace with Germany, as provided by the Versailles Treaty of 1919. The court noted that "Wimbledon, belonging to a nation at that moment at peace with Germany, was entitled to free passage through the Canal". 48 Therefore, as customary law provides, innocent passage is the right of States and its denial would be abuse of sovereignty.

\section{FUNCTIONS OF INTERNATIONAL DIPLOMACY}

It's vital to note that since the era of decolonialization, diplomacy on the international level has been promoted in three main dimensions; the first dimension is between the developed states, secondly, is between the developing states, and lastly is between developing and developed states which is least as its priority which ought not to be so, because this sector presents a serious challenge to the society at large which the states are not ready to accept. ${ }^{49}$ Hence to this end trained diplomats with ideas and visions are needed to develop international diplomacy in order to meet each other's need in the international community without bias for the development and benefit of all. ${ }^{50}$

\footnotetext{
48 World Court - international third-party dispute settlement institutions http:// www.worldcourts.com/pcij/eng/decisions/1923.08.17_wimbledon/, 15 May 2007.

49 C. Chatterjee, op.cit., p. 57.

50 Sovereignty and the global community: the quest for order in the international system, ed. by H.M. Hensel, Hants, England: Burlington, VT: Ashgate, Aldershot c2004.
} 
Hence, in a nutshell the function of international diplomacy is to develop international cooperation and resolve differences either political, economic, attititudinal between states based on two platforms; national[ bilateral] and non-bilateral [regional or universal]. ${ }^{51}$

\section{INTERNATIONAL DIPLOMACY - A FLEXIBLE ATTITUDE TO THE CONCEPT SOVEREIGNTY}

In which ways international diplomacy can help adopt a flexible attitude to the concept sovereignty is intended to be answered in this final part of this paper. International Diplomacy is a tool used by the States mainly to promote peace and cooperation through economic development where, this economic and trade diplomacy will lead to development of political diplomacy ${ }^{52}$.

Chatterjee points out that economic diplomacy has been the prime source of diplomatic relations since Middle Ages and establishment of economic relations is considered as the first step of developing political relations. Reciprocal relations between States is the essence for the survival of a State according to Chatterjee. States should be aware of the fact that they may not practice their sovereignty in its absolute form as they do within their territories.

What they should bear in mind is the necessity of flexible sovereignty, to be beneficial from that cooperation. As Chatterjee suggests, international organisations are the grounds where mutual interests of States can be secured. Therefore, States should use international organisations to increase their cooperation, which is called "cooperative sovereignty". ${ }^{33}$ Cooperative sovereignty would thus enable the States to use their sovereignty in a flexible manner.

To conclude this part, it is also crucial to highlight that international diplomacy can help adopt a flexible view of sovereignty in two ways. First,

51 R.P. Barston, Modern Diplomacy, Longman, London 2006, p. 128.

52 Redefining sovereignty in international economic law, ed. by W. Shan, P. Simons and D. Singh, Oxford: Portland, Or.: Hart 2008.

53 C. Chatterjee, op.cit., p. 65. 
developing and maintaining friendly relations between states through regional economic arrangement either by means of association agreements or rather by negotiating membership with such arrangements. ${ }^{54}$ Second, developing new ideas in the form of resolutions or conventions at the UN level, which will be beneficiary to the entire international community. ${ }^{55}$

Thus, it therefore means that diplomats are needed to be multi-dimensional experts, that is they must have a broad knowledge of power politics, the politics of international economic relations, also coupled with this is that they must have a wide knowledge of the historic ties of the state in question for the enhancement of successful interaction with foreign government. In addition, in order to achieve this function diplomats must have the faculty to negotiate, conciliate and as well as to settle disputes and issues too. ${ }^{56}$

\section{CONCLUSION}

Throughout history, sovereigns tended to use their powers in an abusive manner. In the past, the rulers maintained a rigid view of sovereignty in order to challenge the absolute rule of the Church over State matters. However, emergence of modern system of international law changed the way the relations are handled. Increased cooperation amongst states initially through economic and therefore diplomatic relations, achieved through the establishment of modern nation-states, based on the national and territorial sovereignty.

Respect to each other in State-to-State relations, deriving from the principle that all States are equal, is at the core of international diplomacy. Therefore, States in order not to lose respect in the eyes of others, should use their sovereignty in a flexible manner, especially through participating within international organisations, which should be seen by all States as a platform to receive common gains.

\footnotetext{
54 Resolutions 1803 of 1962 entitled Permanent Sovereignty over National Resources.

55 Ibidem.

56 Ibidem.
} 
The only way to prevent States to use their powers rigidly should be through cooperation through economic development which will open the way of political diplomacy. The importance and role of international organsations is at the utmost level when trying to promote cooperation between States. 